\title{
Standing at a Crossroads: The Building Trades in the Twenty-First Century
}

\section{Mark Erlich and Jeff Grabelsky}

American building trades unions have historically played a critical and stabilizing role in the nation's construction industry, establishing uniform standards and leveling the competitive playing field. Union members have enjoyed better than average wages and benefits, excellent training opportunities, and decent jobsite conditions. But in the last thirty years the industry has undergone a dramatic transformation. This article describes the decline in union density, the drop in construction wages, the growth of anti-union forces, the changes in labor force demographics, the shift toward construction management, and the emergence of an underground economy. It also analyzes how building trades unions have responded to these changes, identifies structural impediments to union renewal, and proposes strategies for building trades unions to reassert their presence and power.

The curved facade of a new US\$65 million Salt Lake City public library is made up of 2,000 individual pre-cast concrete panels. Arriving on giant flatbed trucks in a total of 140 separate shipments, the 10-ton loads of panels were driven from Pretesca, a factory outside of Mexico City, to Utah. The library's general contractor and architectural team had sought bids from pre-cast plants in Phoenix, Denver, and Las Vegas, but, according to project manager Steve Crane, 'Pretesca's low-cost labor made up for the higher shipping costs, and they came in cheapest.' The fact that the substantial trucking costs of a 2,350-mile journey did not eliminate the savings realized by low-waged labor in a Mexican plant is an indication of the gross wage disparity between the two countries. In this case, the domestic labor premium cannot be attributed to high union wages. The three competing southwestern factories were not unionized and Utah's on-site construction labor force is overwhelmingly non-union and, for that matter, often of Mexican background. ${ }^{1}$

There is nothing new about international participation in the United States economy. Producers of auto, steel, textiles, electronics, and other durable goods are disappearing from the American scene, replaced by low-waged competitors in developing countries. But construction had been largely immune to the dynamics of global production. The physical creation of buildings, unlike cars, shirts, or televisions, does not lend itself to overseas assembly, in part or in whole, as long as the object is the ultimate placement of the product on a parcel of land in an American city.

Construction has been considered the largest of the non-service sectors to stand on the sidelines and watch the globalization parade pass by. Construction employers traditionally hired a workforce that lived in or near their projects' communities. Every city or town had its own home-grown group of building trades workers, generally accounting for about five percent of an area's total workforce. The trades offered young men well-paying jobs without their having to pursue a college degree or professional career. The work may have been insecure-the

\footnotetext{
${ }^{1}$ Millman, 'Blueprint for Outsourcing.'
} 
unemployment rate in construction is typically double that of all other industries - but that was inherent in an industry of short-term projects subject to the vagaries of business cycles and seasonal swings. An individual might work for dozens of employers on hundreds of sites over a lifetime, but he was part of a mobile yet stable community of trades workers that operated within defined geographical boundaries.

Construction is a trillion-dollar industry employing over six million workers. Despite the cyclical nature of construction, employment among the industry's half million firms has steadily risen over the past thirty years. And while the industry is now characterized by increasingly consolidated national and multinational building corporations, historically the overwhelming majority of construction workers were employed by firms of fewer than twenty workers.

During most of the post-1945 era, a tradesman could hope for and expect one of the higher standards of living available to blue-collar workers. Trade unions had gained a foothold in the industry by the late nineteenth century and their members were mockingly labeled labor aristocrats because of the sizable gap between construction and factory earnings. The union presence brought relatively high hourly wages and, in time, well-run training programs and an impressive range of benefits. From a contractor's perspective, trade unions added a measure of stability to a wildly unstable business. The unions served as a hiring hall for employers whose workforce expanded and contracted on a weekly basis. The cost of the apprenticeship programs was spread out across the employer community so that no single contractor had to bear the financial burden of training employees. The master agreements set a uniform wage standard in an area, creating a level playing field for labor costs, thereby reducing the volatility of the industry's constant bidding wars. In exchange for these union functions, building employers provided better than average compensation and developed a work environment that served to recruit and retain a steady stream of qualified workers.

Today, it has become more difficult to recruit new entrants into the field because the status of construction jobs is diminishing. 'Everybody thinks that construction is the armpit of jobs,' a Florida union official told a Wall Street Journal reporter. 'No parent wants their kid to be a construction worker.' ${ }^{\prime 2}$ A 2000 Clemson University survey of 1,800 construction craft workers revealed that 70 percent did not want their children to take up their career path. ${ }^{3}$

Changes in the day-to-day tasks of trades workers do not explain construction's shifting status perceptions. In fact, construction is one of the major industries least affected by technological change and innovation. Craftsmen still use some tools and techniques that have been around for a century or longer. Weather conditions can still be unbearably hot in the middle of summer and insufferably cold in a freezing winter. The job remains dirty, difficult, and dangerous. How has a career in the construction industry been transformed from a legitimate path to the American Dream to one that many avoid?

The seismic shifts in the industry date back over thirty years and were driven by a combination of factors that dramatically weakened the presence and power of building trades unions. In the 1960s, the majority of construction activity in the US was performed on a union basis. As the military commitment in Vietnam escalated and the American economy heated up, the supply of skilled laborers contracted, allowing building trades unions to exercise what Fortune magazine described as 'murderous bargaining power' and win increasingly rich contracts for their members. ${ }^{4}$ Construction contractors simply passed on the rising costs of these

\footnotetext{
2 Perez, 'Construction Industry Split,' F1.

${ }^{3}$ BNA Construction Labor Reports 46, no. 2296 (2000): 920.

${ }^{4}$ O'Hanlon, 'Unchecked Power of the Building Trades,' 102.
} 
collective bargaining agreements to corporate users who were engaged in major expansion projects. In response, corporate owners formed the Construction Users Anti-Inflation Roundtable (later renamed the Business Roundtable) in 1969. They launched a campaign and issued a series of reports intended to undermine the strength and vitality of construction unions, recommending changes in contracting practices, job referrals, and training programs. Some giant firms, like Dow and Du Pont, refused to consider bids from union contractors, and others contracted with fledgling non-union builders in an effort to promote an alternative to unionized construction.

The legal and regulatory environment also impacted building trades unions. During the 1970s, unions fought to pass a common-situs picketing bill that would have allowed a single union engaged in a dispute with one of many contractors on a construction site to picket every point of entry to the site and thus potentially shut down the entire project. But in 1976, President Ford vetoed the bill and today construction unions are still hamstrung by requirements that picketing occur only at an arbitrarily determined 'neutral' gate. In 1977, the National Labor Relations Board (NLRB) issued the Kiewit decision, which loosened restrictions on 'doublebreasting,' thus making it easier for unionized contractors to establish non-union subsidiaries and escape the obligations of their contractual agreements with building trades unions. Within ten years, eight of the top ten American building contractors were double-breasted. In 1987, the Board decided in Deklewa that unionized employers who had signed pre-hire agreements with building trades unions were no longer obligated to negotiate successor contracts, further weakening the collective bargaining system that had served and stabilized the construction industry well for several decades.

A rapidly expanding non-union labor market grew with the industry's expansion as exclusionary membership policies prevented workers from joining building trades unions. For example, from 1965 to 1990 , the electrical construction workforce almost tripled in size-from 200,000 to 550,000 -while International Brotherhood of Electrical Workers (IBEW) construction membership remained virtually unchanged at about 140,000. As a result, union workforce density among construction electricians dropped from about 70 to 25 percent in a single generation. ${ }^{5}$ This process was common across all the trades. It is difficult to track and measure union membership and density in the construction industry because of the transient nature of the workforce. But, according to the Building and Construction Trades Department (AFL-CIO), from 1973 to 2002 union membership declined from 1.6 to 1.2 million, while the unorganized construction workforce grew from 2.5 to 5.5 million. Consequently, union density dropped from 39.5 to 17.4 percent during that period of time. ${ }^{6}$ The most recent data from the Bureau of Labor Statistics indicate that the trend is continuing with density falling to 14.7 percent in 2004.

This process of decline has a geographic dimension. In the mid-1970s, construction union density in 22 states was between 30 and 50 percent and in seven states it was over 50 percent. In the mid-1980, construction union density in 11 states was between 30 and 50 percent and was over 50 percent in only two states-Illinois and Hawaii. By the mid-1990s, no states had a construction workforce that was over 50 percent unionized and in only six states was density above 30 percent. This regional dynamic contributed to one of the defining characteristics of the contemporary construction industry - a shrinking number of urban markets where building trades unions remain relatively strong and provide decent wages and benefits for their members, and

\footnotetext{
${ }^{5}$ Data provided by International Brotherhood of Electrical Workers.

${ }^{6}$ Data provided by Building and Construction Trades Department (AFL-CIO).
} 
vast areas where, according to some international union presidents, "we are not even in the game.' 7

Declining unionization did not occur uniformly across every segment of the industry. Because building trades unions focused primarily on the large industrial projects that consumed the lion's share of construction dollars in the 1960s and 1970s, they remained relatively strong in that segment of the industry. But their presence on commercial and residential projects diminished, a problem that became more severe as relative expenditures on residential construction increased. According to Laborers president Terry O'Sullivan, in 2004 about 57 percent of every construction dollar was spent in the residential segment, where 'we have virtually no presence. 8 Like the Laborers, most building trades unions have primarily focused on retaining a presence in the industrial, heavy highway, and large commercial segments of the industry. This has contributed to another defining characteristic of contemporary constructionlarge and growing segments of the industry are outside the union sphere of influence even in the large urban markets where overall union presence remains relatively strong.

Declining union density may have been a serious problem for the building trades, but it was hailed by corporate executives, like Charles Brown, former CEO of Du Pont and a leader of the Business Roundtable, who wrote, 'The construction industry was monopolized by the union segment with no apparent alternative in sight. Fortunately for all of us, the capitalistic system worked again. "Free market"' forces prevailed." Construction users benefited from those 'free market' forces in the short run, but over time they bore a cost. Even in the short run, workers in the industry paid a price.

Construction workers - union and non-union, alike-now tend to work harder, for less money, and under harsher conditions. As a result of the rise of the Roundtable and the anti-union Associated Builders and Contractors (ABC), and the broad-based attack on labor, building tradesmen, once in the upper echelon of American workers, have seen their occupations slip to the low status job that is more characteristic of construction workers in other parts of the world. ${ }^{10}$ In 1967, construction employees in the United States earned more than industrial workers in petro-chemical refining, steel mills, motor vehicles, aircraft, or chemicals; by 1997, construction workers earned less than employees in each of these five industries. As recently as 1983, median weekly earnings in the construction trades exceeded the median for all workers by 20 percent. In a remarkable drop in what could be characterized as a 'labor aristocracy index,' the difference between construction workers and all other workers was only 3 percent in 1999. ${ }^{11}$ The Building and Construction Trades Department (AFL-CIO) reports that between 1973 and 2002 average hourly earnings for all construction workers declined from US\$25.27 to US\$20.85, or 17.5 percent. $^{12}$

But an analysis that focuses on gross numbers for all construction misses the underlying reality of an increasingly bifurcated industry in the contemporary United States. Workers in the trades are in one of two separate worlds. In and around urban areas in the northeast, midwest, and the West Coast, many craft workers are compensated under the terms of collective

\footnotetext{
${ }^{7}$ Interviews with Terry O'Sullivan, president, LIUNA (23 November 2004) and Doug McCarron, president, UBCJA (11 January 2005).

${ }^{8}$ Interview with O'Sullivan.

${ }^{9}$ Engineering News Record, 16 December 1982, 132

${ }^{10}$ Wells, 'The Construction Industry,' 13.

${ }^{11}$ Eisenberg, 'Construction Wages and Labor Supply,' 7. Since union rates are still relatively higher, non-union construction workers are absorbing a disproportionate share of falling construction wages.

12 Data provided by BCTD.
} 
bargaining agreements. Even many nonunion contractors in those areas pay lower but comparable rates, for fear of losing their employees to unionized companies. These union members continue to receive higher than average blue-collar wages, health insurance, and generous retirement benefits. When the union apprenticeship programs open their ranks, there is no shortage of applicants because the building trades in these areas still have a reputation as desirable careers for young workers.

On the other hand, the conditions of non-union construction workers, especially in the southeast, southwest, Gulf Coast, and Rocky Mountain states, have been so degraded that there is a constant complaint about labor shortages. Even in the more unionized west, a 1995 survey of contractors found that 56 percent of the union employers had no issues with the supply of manpower while about 90 percent of the open shop firms did. ${ }^{13}$ As the construction boom of the late 1990s developed, the shortage of skilled labor in the south became a constant subject in industry journals.

In a moment of candor, Frank Yancey, senior vice-president of Kellogg, Brown \& Root (KBR), the nation's third-largest contractor, noted that a Gulf Coast construction worker 'is not a craftsman today, it is a poor person. ${ }^{14}$ In the summer of 2000 , Yancey told his colleagues at the Construction Industry Institute, "If low pay was a felony, I think most of us would be on death row today. ${ }^{15}$ Ted Kennedy, chairman of BE\&K (a multinational construction and engineering firm), and a long-time spokesman for the $\mathrm{ABC}$ and anti-union forces in the industry, commented, 'We reap the crop we sow, and we have not sown enough seeds . . I have a belief that wages are way too low. ${ }^{16}$ Yancey and Kennedy are representatives of prominent builders and industry leaders with clout, but their comments are hollow. Competitive pressures bar the likelihood of unilateral pay hike policies by KBR, BE\&K, or any other company. Wages in the areas their companies work in have been dropping steadily for thirty years and this trend shows no signs of abating.

In 2001, Edward Steimel issued a report on the state of the industry in Louisiana. Steimel had been the president of the Louisiana Association of Business and Industry and had led the successful campaign to pass a right-to-work law in the state in 1976. Twenty-five years later, Steimel argued that 'the pendulum has swung too far.' Noting that average construction wages in Louisiana were US\$10 an hour lower than in states like Michigan and New Jersey and even US\$3 an hour less than in neighboring Texas, Steimel said that the attraction of higher pay in other states or better-paying factory jobs in Louisiana was the cause of the extreme shortages of skilled construction workers. ${ }^{17}$

With wages too low to attract the industry's traditional demographic base of recruits, contractors turned to immigrants to fill the vacuum. If the standard forms of international competition-outsourcing and overseas production-did not apply to construction, then globalization could come in the back door. Thousands of hopeful workers-some documented, some not-crossed the Mexican border every week, fanned out across the southern and western states, and joined immigrants from Central America, Latin America, and Eastern Europe to work on construction projects all across the country. Some observers have suggested that Hispanics will make up nearly half of the nation's construction workforce by 2010 .

\footnotetext{
${ }^{13}$ Engineering News Record, 25 December 1995, 34.

${ }^{14}$ Engineering News Record, 18 September 2000, 14.

${ }^{15}$ BNA Construction Labor Reports 47, no. 2339 (2001): 697.

${ }^{16}$ Engineering News Record, 18 September 2000, 14.

${ }^{17}$ BNA Construction Labor Reports 47, no. 2350 (2001): 1005-6.
} 
Current government estimates place the total number of undocumented workers in the United States around nine million, but private researchers claim that an accurate number might be closer to 20 million. ${ }^{18}$ No one knows how many are working in construction, but undocumented immigrants are clearly the industry's backbone in many areas and even in subsectors like residential and light commercial in still strong union markets. 'If the government clamped down on all the people who are not fully legal and kicked them out,' said Don Hiatt of Tri-State Drywall of Rockville, Maryland in the wake of calls for tightened borders after 9/11, 'construction would shut down.' 19

Today a union carpenter in New York City will likely earn five times more in wages and benefits than a carpenter in Orlando for the same work. Still, an immigrant who works as a wood-framer or drywaller in Florida for a portion of the year, sending money home on a regular basis, can earn eight times as much as he would in his native Mexican village ${ }^{20}$ One indicator of the growing immigrant presence in the workforce is the fact that monetary remittances from the US to Mexico tripled to US\$13.2 billion between 1995 and $2000 .^{21}$ Surely, the chance to boost family earnings motivates new immigrants, but the vulnerability of their legal status forces them to accept whatever conditions are offered. As Laborers President Terry O'Sullivan has noted, current immigration policies as well as all the proposals for temporary worker programs do not 'free a worker to voice concern over job safety or wages.' 22

The stories of employer abuse are widespread. A Houston developer rejected a US\$325 000 bid from an abatement company as part of his planned renovation of an old hospital building. Instead, he hired ten undocumented Mexican farm workers for US\$2000 apiece to remove fireproofing material that he neglected to inform them was laced with toxic asbestos. ${ }^{23}$ The backdrop of deportation serves as an effective deterrent to protest. During a Carpenters Union campaign against Utah Structural Coatings in Salt Lake City, the owner threatened deportation and fired over forty undocumented employees, effectively undermining all organizing efforts. ${ }^{24}$ Under the current administration employers hiring undocumented workers have little to fear. United States Citizenship and Immigration Services (formerly Immigration and Naturalization Services) enforcement actions against employers and undocumented workers have dropped sharply since 1997 , from 18,000 to fewer than 1,000 arrests in $2002 .{ }^{25}$ This dynamic is as common on publicly funded jobs as it is on private projects. When a rare government raid resulted in the deportation of 32 undocumented immigrants working on a US\$163 million federal courthouse in Miami in 2003, the contractor, Jim Renaud of Capform, evinced little sympathy for the disruptions in his workers' lives, but complained that his firm lost 'half a million and five weeks of work. 26

Policymakers and business leaders justify minimal immigration enforcement practices because they argue that US citizens are uninterested in these jobs and the work has to be completed. As President George W. Bush claimed, 'there are some jobs in America that

\footnotetext{
${ }^{18}$ Justich and $\mathrm{Ng}$, 'Underground Labor Force,' 2.

${ }^{19}$ Engineering News Record, 22 October 2001, 38.

${ }^{20}$ BNA Construction Labor Report 47, no. 2321 (2001): 138.

${ }^{21}$ McTague, 'Going Underground, ' 18.

${ }^{22}$ Engineering News Record, 19 January 2004, 10.

${ }^{23}$ BNA Construction Labor Report 47, no. 2323 (2001): 214.

${ }^{24}$ Engineering News Record, 31 July 2000, 15.

${ }^{25}$ McTague, 'Going Underground,' 19.

${ }^{26}$ Engineering News Record, 19 January 2004, 10.
} 
Americans won't do and others are willing to do. ${ }^{27}$ Bush has it backwards. American citizens want the jobs; they do not, however, want to work for the minimal wages that the jobs now pay. When the compensation is reasonable, manpower shortages quickly disappear.

The management structure and organization of work have also changed over the past thirty years. Throughout the first three-quarters of the last century, general contractors stood at the center of the industry. Whenever a private or public owner sought to build a project, general contractors bid a fixed price to perform the work. The successful bidder was the contact with the owner as well as the direct employer of many of the people who would bring the project to completion. General contractors typically employed carpenters and laborers and, in some cases, bricklayers, ironworkers, operating engineers, and painters. The mechanical portions of a project were subcontracted to specialty electrical, plumbing, and other contractors that usually had prior business relationships with the general contractor.

The founding owner of a general contracting firm had generally worked his way up the ranks and was personally familiar with the daily challenges facing the craftsmen he employed. If direction of the firm was later handed off to the next generation, there was an assumption that the heir to the throne should spend some time in the field before moving into the office. Job-site superintendents were also usually craftsmen themselves. Between 1967 and 1997, general contractors cut their share of construction worker employment from 35 percent to 24 percent of the labor force; specialty trade subcontractors, on the other hand, went from 48 percent to 63 percent. ${ }^{28}$ The self-performing general contractor that was thoroughly integrated into every operation of a project evolved into a construction manager whose responsibility was limited to managing and coordinating a series of specialized subcontractors that employed the men and women who carried out the on-site tasks.

These new highly capitalized brokers have divorced themselves from hands-on construction work and focused on business development and project management. They are no longer producers of goods; they 'have turned into service companies, finding clients and marketing products that are then produced by subcontractors.' ${ }^{29}$ Construction management executives are building professionals with limited connections to the tools, craft knowledge, and working lives of the trades workers on the job. Even their job-site superintendents are as likely to be graduates of civil engineering schools as of the industry's home-grown apprenticeship programs. All risk and liability are shifted from the hands of the construction manager to the subcontractor. The price for estimating mistakes, workplace injuries, materials delays, or any of the other standard hurdles is borne entirely by the subcontractor, who is also responsible for the management of labor relations.

The growing use of immigrant workers meshes with the structural trend toward subcontracting. As general contractors/construction managers shift on-site labor responsibilities to an array of mobile subcontractors, intermediaries such as temporary employment agencies or individual labor brokers emerge that seek to provide non-union firms some of the referral services offered to unionized contractors by a union hiring hall. Undocumented Latino workers frequently operate under the direction of a coyote, an operative who arranges for border crossings out of Mexico and job placements on construction sites in the US. They make travel and lodging arrangements and negotiate the financial terms with the contractors. They do not

\footnotetext{
${ }^{27}$ Fletcher, 'Bush Immigration Plan,' A6.

${ }^{28}$ Bosch and Philips, Building Chaos, 317.

${ }^{29}$ Wells, 'The Construction Industry,' 21.
} 
need any particular construction or supervision skills, just a cell phone and a list of available workers.

The increased use of undocumented workers also complements the growing presence of the underground economy in construction. It is a small step for an unscrupulous employer to move from hiring undocumented workers to operating entirely off the books - or vice versa. There are a wide variety of illicit employment relations, ranging from handling all transactions in cash to a sophisticated system of misclassifying employees as 'independent contractors' in order to avoid tax, insurance, and a host of regulatory obligations.

An army of lawyers and accountants has emerged to advise construction employers how to shift employees off payrolls into self-employed status. Internal Revenue Service (IRS) spokesmen recognize that 'more and more people are being treated as independent contractors' and construction is a prime culprit. ${ }^{30}$ Legitimate contractors that maintain payrolls and play by the rules are at a competitive disadvantage against firms that misclassify and, thereby, realize substantial labor cost savings. As their less scrupulous peers repeatedly submit lower contract bids, they are forced to adopt the same fraudulent and illegal practices or watch business opportunities evaporate. Workers who are labeled independent contractors are not eligible for legally required protections, such as unemployment, workers' compensation insurance, mandatory overtime, and other wage laws.

While data on lost revenues from unreported sources are, by definition, sketchy, a few studies indicate the extent of the problem. A US Department of Labor report suggested that misclassification results in a loss of US $\$ 198$ million a year to various unemployment insurance trust funds and 80,000 workers who are entitled to benefits are not receiving them. ${ }^{31}$ Massachusetts, a state with a relatively strong regulatory environment, reportedly loses US\$152 million in state income taxes due to misclassification. ${ }^{32}$ In Florida, the workers compensation program collapsed completely under the weight of construction employer fraud. Though premiums were the second highest in the nation, insurance carriers refused to issue new policies and medical providers began to refuse workers compensation patients because they feared lack of reimbursement from a fund that contractors had shorted US $\$ 1.3$ billion a year in premium payments. $^{33}$

Some researchers have attempted to estimate the full impact of the underground labor force-not just what is revealed in official data sources. For example, a Bear Stearns report claims that the US Treasury is actually losing US\$35 billion a year in income tax collections because of the number of jobs that are now entirely off the books. ${ }^{34}$ The overall underground economy is estimated to be nearly US\$3 trillion a year, nine percent of the real economy, and the gap between taxes collected and taxes that should be paid is expected to be as high as US $\$ 400$ billion in $2005 .^{35}$

\footnotetext{
${ }^{30}$ McTague, 'Going Underground,' 17.

31 'Independent Contractors: Prevalence and Implications for Unemployment Insurance Programs', US Department of Labor, February 2000, iv.

32 'The Social and Economic Costs of Employee Misclassification in Construction', Harvard Construction Policy Research Center, December 2004, 2 .

33 'A Study on the Magnitude of Loss of Workers' Compensation Premiums in 1997 Due to Employer Fraud and Exemptions in the Florida Construction Industry', Construction Education Concepts, March 2001, 28. See Governor's Commission on Workers' Compensation Reform Final Report, 31 January 2003.

${ }^{34}$ Justich and $\mathrm{Ng}$, 'Underground Labor Force,' 2.

${ }^{35}$ McTague, 'Going Underground,' 17.
} 
The decline in union density, the drop in construction wages, the growth of anti-union forces, changes in labor force demographics, the shift towards construction management, and the emergence of an underground economy provide the backdrop for a very different industry. Legitimate employers - union or nonunion - that provide a living wage and benefits for their employees are constantly looking over their shoulders at the legions of subcontractors that play by a different set of rules.

This reality has forced building trades unionists to recognize that their world has changed. Virtually every aspect of union affairs in the construction industry was predicated on an assumption of power that was derived from relatively high union density and union control of the skilled labor supply. But as the non-union workforce rapidly expanded through the 1970s and 1980 s, union density continued to decline and union control began to unravel. Rather than confronting the fundamental problem by organizing the non-union labor force, many building trades leaders seemed trapped in denial. 'We refused to accept that the world was changing and continued doing what we had done for decades,' explained one leader. ${ }^{36}$

Some of the choices the building trades made were counterproductive. For example, in the 1960s and 1970s, huge industrial construction projects offered lucrative contracts to signatory employers and steady employment for union members, both of whom abandoned less attractive commercial and residential projects that were gradually captured by non-union contractors. This gave the open shop a foothold in traditional union submarkets. In many regions these megaprojects generated labor demands that exceeded the union supply. But rather than exploiting the tight labor market conditions to organize more members, local unions invited 'travelers' from other jurisdictions to help staff these jobs or issued temporary permits to nonunion workers who were never offered union membership. These 'permit hands' acquired new and valuable skills working on union jobs, but they also developed deep resentments toward the union because of its exclusionary membership policies. These skills and resentments were to come back to haunt unions in the years ahead.

There were building trades leaders who recognized the threat posed by non-union contractors that underbid signatory employers and won projects that might otherwise have employed union members. These leaders explored ways to make union contractors more competitive. Initially this meant looking for cost savings that could be achieved through direct concessions to employers, sometimes on targeted jobs and other times through wage freezes and givebacks in collective bargaining agreements. In the late 1970s and early 1980s, national agreements were negotiated for major construction projects that offered union contractors relief on wages and work rules. Local unions also negotiated concessionary deals to help local contractors withstand the competitive pressures of low-bidding non-union builders. In 1984, wage cuts and freezes actually outnumbered wage hikes in union contracts. ${ }^{37}$ Unfortunately, as non-union competition drove down union scales, non-union wages followed suit.

Building trades leaders soon devised more creative ways to cut direct labor costs. For example, market recovery funds were established to provide subsidies to unionized contractors who bid on projects the local union regarded as strategically important. Some believed these efforts enabled unionized employers to capture work they might otherwise have lost to the nonunion competition, but others feared the funds enriched signatories and developers without stemming the tide of the open shop. Competitiveness strategies were not confined to labor cost

\footnotetext{
${ }^{36}$ Interview with Tim Nichols, former secretary-treasurer of the Michigan State Building and Construction Trades Council (12 June 1997).

37 Engineering News Record, 16 January 1985, 28.
} 
cutting alone. Union leaders worked closely with their business counterparts to elevate labormanagement cooperation, to promote the advantages of building union to construction users and the consuming public, to minimize unnecessary job-site conflicts that delayed projects (and thus raised the costs of union construction), to enhance the skill and productivity of union members through training and upgrading, and to eliminate archaic work rules that disadvantaged union contractors.

Unions have also negotiated project-specific agreements requiring the exclusive use of union labor in exchange for special provisions that enhance productivity, avoid labor disruptions, and ensure construction completion dates in both the private and public sectors. In 1993, the United States Supreme Court issued a landmark decision in the Boston Harbor case authorizing the use of Project Labor Agreements, or PLAs, on certain public construction projects. Antiunion critics have claimed that PLAs increase construction costs and disadvantage open shop contractors. Project Labor Agreements advocates dispute these claims, point out important labor cost savings, and suggest that these project-specific agreements serve the public interest. Many unionists praise these Project Labor Agreements as effective tools to fight the open shop. But others argue that in some markets PLAs allow non-union contractors to cherry-pick projects by agreeing only to their project-specific terms without having to sign area standard collective bargaining agreements. As such, these critics suggest that PLAs may contribute to the dissolution of collective bargaining in the construction industry.

In many markets, local unions used direct action to neutralize the non-union threat. They hand-billed and picketed non-union job-sites, claiming that open shop contractors were undermining community standards. These tactics occasionally embarrassed companies that were using non-union builders, but rarely persuaded decision-makers to abandon these contractors or to hire union signatories. Sometimes several building trades affiliates engaged in cooperative efforts to pressure large construction users to follow more union-friendly policies, as they did in 1986 with a corporate campaign that persuaded Toyota to build its US\$800 million Kentucky factory with union labor.

In the face of economic pressure from low-cost builders and political pressure from the Business Roundtable, $\mathrm{ABC}$, and their allies in government, construction unionists were also forced into defensive battles to preserve prevailing wage laws that helped protect longestablished union standards. At the national level, regular attempts to repeal or gut the DavisBacon Act were turned back, but changes in regulatory enforcement gradually weakened the protection of prevailing wages on federally financed construction projects. In the last two decades, 10 of 41 states with 'little Davis-Bacon' laws repealed the legislation; the building trades led successful fights to retain prevailing wage laws in Massachusetts in 1988 and in Oregon in 1994.

None of these union efforts prevented the steady erosion of industry standards or addressed the underlying problem of a growing non-union workforce. In the 1980s, a small but growing number of union leaders began to argue for a renewed commitment to organizing as the ultimate solution to the problem of declining union power-organizing the work, the contractors, and the workers. To organize the work, some building trades unions learned to intervene in the construction development process in ways that dissuaded public authorities or private users from awarding jobs to non-union contractors. To organize the contractors, unionists applied top-down persuasion or pressure on targets in ways that conveyed the real advantages of signing a collective bargaining agreement and the potentially costly disadvantages of battling with the union. In relatively strong union markets, the building trades experienced modest success in 
organizing the work and some non-union contractors. In weaker markets, it proved to be exceedingly difficult to check the expansion of the non-union movement without control of the skilled labor supply.

In both strong and weak markets, construction unionists found that organizing unrepresented workers was a tough proposition. It was hard to identify and communicate with workers who moved from project to project and employer to employer. Unions experimented with a variety of tactics to overcome this obstacle, the most creative of which was salting nonunion job sites with union members who went to work for open shop contractors for the purpose of organizing. This tactic proved to be more effective in exposing unlawful conduct on the part of non-union contractors who routinely discriminated against union members and violated numerous laws and regulations than it was in organizing unrepresented workers. In some cases, union salts persuaded non-union workers to join the union, thus stripping employees away from their open shop contractors. But this approach was effective only when the union had an abundance of work. More important, organizers who sought to recruit non-union workers confronted three formidable obstacles: first, the more highly skilled workers-many of whom had sharpened their trade knowledge working on union projects as 'permit hands' in the 1960s and 1970s-were so valuable to their employers that they tended to be treated relatively well; second, workers who had sought and been denied union membership in years past harbored deep resentments toward the locals that had excluded them and were, therefore, reluctant to abandon their current employer; and, third, many leaders and members had not yet rejected their unions' exclusionary membership philosophy nor were they ready to embrace newly organized workers.

For many decades, African-American workers were among the primary victims of exclusion. National unions asserted that they did not maintain a strict color bar but, at the local level, it took determined pressure from civil rights advocates and lawyers throughout the 1960s and 1970s to open up union apprentice programs. By now, virtually all the trades, including the skilled mechanical crafts, have been expanded by affirmative action. The exclusion of women was a different matter because, unlike black men, they were never well represented in the construction workforce. In the last two decades, a host of organizations have prepared and supported women with little or no construction experience to break into the industry's nontraditional jobs and apprentice programs. Despite these efforts, female participation has been stuck at about two percent. Today, the issue of exclusion impacts new immigrants more than any other group of workers.

In the late 1980s, when unions began turning their attention to organizing, their exclusionary membership policies often applied to all non-union workers regardless of race. The policy of exclusion was an obstacle to organizing which had to be dismantled. The IBEW designed a membership education program called the COMET (Construction Organizing Membership Education Training) to address the problem. Delivered by union-based trainers and driven by a participatory pedagogy, the COMET program helped members understand why organizing unrepresented electricians would enable their union to regain control of the skilled labor supply and to rebuild its bargaining strength. ${ }^{38}$ After tens of thousands of members participated in COMET classes, the internal culture of the union began to shift at least enough for far-sighted local leaders to organize non-union electrical workers without facing the wrath of their membership. The IBEW's success with the COMET inspired the AFL-CIO's national Building and Construction Trades Department (BCTD) and each of its 15 affiliates to adopt the COMET program. Many leaders attributed the rebirth of construction organizing in the late

\footnotetext{
${ }^{38}$ Grabelsky, 'Lighting the Spark.'
} 
1980s and early 1990s to this program. 'COMET is the spark that has regenerated our union fervor,' declared one union president in 1994, '[and] entailed nothing less than remaking our own culture. ${ }^{39}$ But building support for organizing and doing it successfully were not one and the same.

In salting campaigns, leverage derived from NLRB or other charges against lawbreaking employers occasionally induced non-union contractors to sign collective bargaining agreements In stripping efforts, open shop employers sometimes signed union contracts to gain access to the local's skilled workforce when faced with sufficiently severe labor shortages. But in both cases building trades locals rarely conducted traditional campaigns through which unrepresented workers organized around their immediate concerns, engaged in escalating concerted activity to force their employers to address those concerns, or generated enough collective power to compel contractors to negotiate and sign bargaining agreements.

By the early $1990 \mathrm{~s}$, some construction unionists began advocating for a more advanced approach to organizing. They argued for mass workforce organizing rather than just individual recruitment. To overcome the futility of organizing one target at a time-and thus encumbering newly unionized contractors with the higher costs of a union contract while their chief competitors remained non-union-these leaders also proposed efforts to pursue multiple targets in single market-wide campaigns. In 1996, the Laborers conducted two market-wide campaigns in New York City, one in the asbestos abatement industry and the other in demolition. Several thousand new members - many of them immigrants from Latin America and Eastern Europewere organized and large portions of both construction sectors were unionized.

Some leaders saw an inherent limitation in this kind of single affiliate campaign. They suggested that no building trades affiliate could achieve lasting success on its own, that no single union could survive as an island of strength in a sea of weakness. These leaders also pointed out that the traditional craft jurisdictions of the union sector were not generally reflected in most open shop markets, and unless one union was prepared to organize 'wall-to-wall' - an unlikely scenario at the time - it was necessary for building trades affiliates to coordinate their efforts in multi-union campaigns.

In 1997, the Building and Construction Trades Department (BCTD) launched the Building Trades Organizing Project (BTOP), a multi-union, market-wide, workforce organizing experiment. Between 1997 and 1999, all 15 BCTD affiliates sponsored this ambitious project in Las Vegas, during an extraordinary building boom that offered what was generally regarded as favorable organizing conditions. With support from the AFL-CIO, over US\$6 million and seventy organizers were dispatched to assist Las Vegas local unions in their organizing efforts and local union membership increased from 18,820 to 25,400 .

The Roofers Union embraced the project's mission of workforce organizing more enthusiastically than many other Las Vegas affiliates. In a model campaign, the union targeted Willis Roofing, which employed about 250 immigrant workers, many undocumented, and was the largest non-union roofing company in Nevada's explosive residential market. The engine of the campaign was an active committee of Willis workers who mobilized their fellow roofers in a series of escalating concerted actions that included delegations, vigils, and unfair labor practice strikes. The faith-based community joined workers in protesting the company's abusive practices, including its failure to pay for overtime and insistence that workers pay for legally required safety equipment. The union augmented the workers' efforts with a comprehensive strategy that involved litigation, pressure on major residential developers, outreach to prospective homebuyers,

39 J. J. Barry, International president, IBEW, Construction Conference Speech, 2 April 1994. 
shareholder actions, and a national mobilization of allies. The combination of worker activity, community support, and creative pressure tactics resulted in a union contract that provided for a substantial raise and full employer-paid pension and health benefits. Willis Roofing also agreed to pay US\$400,000 in back pay for wage and hour violations and US\$100,000 in legal fees to BTOP.

Energized by the victory, the union went on to organize other roofing contractors in Las Vegas and more recently in Phoenix, Arizona. They targeted Diversified Roofing, which controlled about 15 percent of the residential market and employed about 325 workers, mostly Latinos. Using the same kind of comprehensive strategy, the union persuaded Diversified to sign a collective bargaining agreement that provided employees with a wage increase, a health plan, training, and a future pension fund. As former Roofers organizing director and current national president John Martini put it: 'We're not going to wait like we did in Las Vegas. We're going to do a real quick follow-up.' Soon after Diversified signed the Roofers contract, the union distributed copies of the agreement to over twenty other roofing contractors in the Phoenix market. One of the targets said simply, 'I can't afford to fight them. ${ }^{40}$ Despite the Roofers' success, most other building trades affiliates remained ambivalent about the comprehensive organizing model.

The next major multi-trade project was launched by the Department in 2000 in response to the proliferation of temporary agencies in construction. This national campaign-'Temp Workers Deserve a Permanent Voice @ Work' —set out four basic goals: educating local union leaders and members about the temporary agency phenomenon; organizing workers who were dispatched by temporary agencies; unionizing contractors who utilized temporary firm services; and altering how temporary agencies operated to ensure that they followed all relevant regulations. The building trades focused on firms-like Tradesman and TradeSource- that dispatched skilled crafts as well as national day-labor firms-like Labor Ready and Labor Finders. The BCTD drew attention to the ways in which temporary agencies hurt unionized contractors and sought to supplant building trades hiring halls. And, through public scrutiny and legal action the campaign forced some firms to stop charging employees for check-cashing services, or avoiding appropriate workers' compensations premiums. But, the trades had considerably less success in organizing temporary workers or unionizing new contractors.

The successes and failures of these recent efforts have taught a new generation of leaders valuable lessons. There is a growing recognition that, as Ed Sullivan, president of the national Building and Construction Trades Department, says, 'you have to spend your money on organizing. ${ }^{41}$ As recently as 15 years ago, this straightforward statement would have generated controversy and political challenges. Today, a public commitment to organizing is the conventional wisdom, clearly within the mainstream of building trades union leadership thinking. Unions have hosted conferences and hired organizing directors but, too often, in the words of Carpenter president Doug McCarron, 'the rhetoric was there but there was no follow through and no accountability. ${ }^{42}$

A successful program requires the development of a culture of organizing that permeates the entire union, from top to bottom. The leadership, staff, and membership have to embrace and promote an organizing capacity that involves shifting resources, hiring and training organizers, and developing the research capabilities to support top-down, bottom-up, and corporate

\footnotetext{
${ }^{40}$ BNA Construction Labor Report 47, no. 2320 (2001): 101.

${ }^{41}$ Interview with Ed Sullivan, 16 November 2004.

${ }^{42}$ Interview with Doug McCarron, 11 January 2005.
} 
campaigns. The initial indicator of seriousness is, as always, financial. 'Without alternative sources of revenue, you can't organize,' points out Laborers president Terry O'Sullivan. 'When I came in, if I had committed $100 \%$ of the International's budget to organizing, it wouldn't have come close to being enough to grow. ${ }^{43}$

A growth strategy cannot succeed without a thorough examination and possible reorganization of the unions' internal structures. Organizing programs have often bumped up against traditional exclusionary union policies - high initiation fees, multiple and unequal job referral lists, racial discrimination, and the remaining vestiges of 'country-club' unionism. Collective bargaining cannot be exclusively focused on protecting remaining union strongholds and should instead leverage the power of market density to assist weaker areas. For example, the New England Regional Council of Carpenters has successfully leveraged its strength in the highly unionized Boston area to compel contractors to sign agreements covering all six states in its jurisdiction, including much weaker union markets.

The strong suit of the building trades unions is the capacity to provide craftsmen to an industry that still needs skilled workers. For all of the ABC's efforts over the years to establish and publicize alternatives, union training programs enrolled fully 72 percent of all apprentices registered with the Department of Labor between 1989 and 2001. Further, union programs are responsible for 82 percent of all graduating apprentices. While open shop critics charge that unions train generalists in an age of specialization, the evidence suggests that the training remains effective. According to economist Peter Philips, a doubling of the rate of unionization leads to a $10-20$ percent increase in labor productivity. ${ }^{44}$

Too many union leaders cling to the notion that better marketing and promotion of the unions' highly skilled workforce is the primary solution to the open shop challenge. ${ }^{45}$ They recognize that open shop training programs face the constant obstacle of the individual contractor's short-term business orientation and the resulting reluctance to invest in training that will, at best, pay dividends in the future and, at worst, benefit a competitor. The productivity differential is real and the union advantage worth publicizing but the substantially lower pay scales allow non-union firms to bridge the gap and successfully underbid union companies. In time, the knowledge gained from extended on-site experience also begins to compensate for the lack of formal training. 'Our membership is finally seeing that there are a lot of good non-union employees out there, not like before,' says Ed Hill, IBEW president. ${ }^{46}$ Therefore, union training must not only adhere to standards of excellence; it must reflect organizing goals. The curricula have to include the techniques and materials of residential and light commercial construction in addition to the skill sets of the sectors in which the unions have traditionally been based.

At a time when 45 million Americans lack health insurance and the percentage of privatesector workers covered by traditional defined benefit pension plans has been cut in half since 1980, the benefits provided under most building trades agreements stand as an exceptional model. But these union benefits will be increasingly difficult to preserve in the face of intense competitive pressure from open shop employers that do not provide their workers with anything comparable. Small construction employers cannot afford good health and retirement programs

\footnotetext{
${ }^{43}$ Interview with Terry O'Sullivan, 23 December 2004.

44 'A Preliminary Report on Associated Builders and Contractors Apprenticeship Training: Flawed and Failing Initiatives', Building and Construction Trades Department, AFL-CIO, October 2003; Bosch and Philips, Building Chaos, $298,305$.

${ }^{45}$ A number of union strategists argue that a business development approach that 'sells' contractors and owners on the added value of union construction is the single best path to growth. See Breslin, Organize or Die.

${ }^{46}$ Interview with Ed Hill, 16 November 2004.
} 
even if they wanted to without the advantage of the unions' bulk purchasing power. In the face of the Roofers' organizing drive in Arizona, one non-union subcontractor calculated that a union agreement would only add US $\$ 100$ to the cost of every home and acknowledged that 'there are benefits for the employees that I can't otherwise provide. ${ }^{47}$

The collective value of building trades retirement funds is approximately US $\$ 210$ billion. The sheer volume has built a foundation for the strategic use of shareholder activism to complement union organizing goals. Union funds file dozens of corporate governance reform proposals on an annual basis, in part to alter poor business practices of targeted companies and, in part, to create opportunities for discussions with corporate executives regarding construction labor policies. Some funds are being invested to support new union construction, to promote new technologies that union members can install and service, and to retrofit existing structures to enhance safety and expand union employment opportunities.

The very system of benefits that services workers and their families has become a problematic competitive cost factor for union contractors. Annual double-digit inflation in health costs has pushed some collective bargaining hourly health contributions above the level of the minimum wage. The demographic trends of baby-boomer retirements combined with declining membership ranks have placed added pressure on fewer working union members to support more retirees. In 1980, 76 percent of the participants in multi-employer pension funds were active members; in 2001 , the number slid to 50 percent. $^{48}$ In many cases, the benefits portion of a union contract now exceeds one-third of the total compensation package. Only a growth strategy that recruits large numbers of young new workers into the building trades unions can offset this burden.

Building trades unionists pride themselves on their political acumen and activism. Since the world of real estate and development is at the center of every community's policy debates, union leaders recognize the importance of relationships with local politicians and permitting processes. A decision to build a project on a union basis can often be determined by political as much as financial factors. Ultimately, however, political influence on the local, state, and national levels is a numbers game. The 2004 presidential election was a prime example. According to exit polling, union membership was a critical determinant in voter behavior. For example, white male union members voted for John Kerry by 24 percentage points, while white men outside labor's ranks supported George Bush by 26 points. Similarly, union gun owners supported Kerry by 12 points as compared with the general gun-owning public's 20-point tilt to Bush. Yet the impressive internal mobilization efforts were not enough to overcome labor's declining overall numbers. For this reason, Ed Sullivan argues that the building trades should emphasize organizing over political action: 'If you're successful in organizing, you're automatically going to pick up some political clout. ${ }^{, 49}$

Efforts to improve labor relations have become much more common. 'We have to make our contractors more competitive,' says Joe Hunt, president of the Ironworkers. 'If they don't have a job, there's no job for us to work on. ${ }^{50}$ Construction users and owners have responded to these overtures. The fiercely antiunion construction committee of the Business Roundtable reorganized itself as the Construction Users Roundtable (CURT) in 2000, suggesting that the 'committee may have been a victim of its own success in promoting construction cost-

\footnotetext{
47 BNA Construction Labor Report 47, no. 2320 (2001): 101.

${ }^{48}$ PBGC Pension Insurance Data Book, 2003.

${ }^{49}$ VNS Exit Polls, Peter Hart Research; interview with Sullivan.

${ }^{50}$ Interview with Joe Hunt, 16 December 2004.
} 
effectiveness.' Intel executive and CURT president Tom Weise has publicly questioned the validity of the Business Roundtable's earlier recommendations. In the absence of union participation in Roundtable discussions, he suggests the reports were based on contractor-filtered perceptions of unions and tainted by management agendas. The CURT and building trades leaders have been meeting regularly to discuss training, labor supply, substance abuse, and other industry concerns. According to Carpenter president Doug McCarron, one of the labor participants, 'They're saying: "We need you guys. You're the only ones that are doing the training. We did too good a job when we kicked your ass.", ,51

While some owners may recognize the unions' contributions, industry decision-makers still operate in a highly competitive arena, even in the most densely organized environments. Ed Malloy, president of the Building and Construction Trades Council of Greater New York, describes the anti-union mentality of a new breed of developers. 'They only see two issues-one is control of the job and the other is the bottom line. ${ }^{52}$ Unionized contractors are not always the best allies of an organizing and growth approach. Like some members, union firms can view new signatories as competition in a static market, rather than as participants in an expanding one. In the final analysis, as crucial as quality training, sophisticated benefits programs, and labormanagement cooperation may be, as Laborers president Terry O'Sullivan says, 'market share drives the whole equation' and is the factor that will determine conditions in the industry. ${ }^{53}$

In 1995, when John Sweeney was elected president of the AFL-CIO in the Federation's first contested election in forty years, a new spirit of hope was injected into a movement that appeared to be trapped in a downward slide. Labor activists were energized by a vision of growth and power that would come from intensified organizing and political work. But even after ten years of substantial efforts in both organizing and politics, union density slipped from 14.9 percent to 12.5 percent (only eight percent in the private sector) and labor-supported candidates lost the last two presidential elections. This reality has sparked a debate in the labor movement about whether a dramatic change in strategic direction may be necessary to revitalize labor's fortunes. The emerging debate about labor's future touches every sector of the movement. The building and construction trades are no exception.

Building trades leaders have publicly proclaimed their steadfast dedication to organizing and growth, while density in their industry has continued to fall. Why have construction unionists not achieved greater success in translating their rhetorical commitment to organizing into real world growth? What obstacles stand in the way of more measurable progress in raising unionization rates, recapturing lost markets, and rebuilding union strength? Are there structural impediments that have hindered the conduct of the multi-union, market-wide, workforce campaigns that many union leaders believe are necessary? Do building trades unionists lack the strategic imagination needed to revitalize their movement?

One issue that has received particular attention recently is the 'architecture' of the House of Labor. ${ }^{54}$ For construction unionists there are at least four interrelated structural issues that have confounded efforts to reverse their declining strength:

\footnotetext{
${ }^{51}$ Engineering News Record, 15 May 2000, 15; BNA Construction Labor Report 50, no. 2499 (2003): 1206-7; interview with Doug McCarron, 11 January 2005.

52 Interview with Ed Malloy, 25 January 2005.

${ }^{53}$ Interview with Terry O'Sullivan, 23 December 2004.

${ }^{54}$ Lerner, 'An Immodest Proposal.' This was one of the first articles that helped spark the debate about labor's future.
} 
1. There is a mismatch between national union structures based on local affiliates that evolved in local markets, and the actual structure of the modern construction industry, which is increasingly dominated by regional and national contractors operating in regional and national markets

2. There is a mismatch between the need for a coherent and coordinated organizing strategy among locals within the same national union and the enduring tradition of local autonomy evidenced in all building trades affiliates.

3. There is a mismatch between the structure of the Building and Construction Trades Department and its 300 constituent councils - which are voluntary associations that lack the power and authority to conduct coordinated organizing campaigns-and the challenge of unionizing a trillion-dollar industry with over five million unrepresented workers.

4. There is a mismatch between the structure of the unionized sector of the industry, with its 15 separate affiliates representing different but increasingly overlapping craft jurisdictions, and the dynamics of the now dominant non-union sector, where traditional jurisdictional lines are neither reflected nor respected.

In the case of the first mismatch, building trades locals were established in local construction markets where unions organized the local labor pool and local employers operated in those local markets. Responsibility for organizing and bargaining resided primarily with the local unions. But the industry is increasingly characterized by regional, national and even global contractors whose operations are no longer confined to local markets. Virtually every local union confronts contractors who operate in multiple local jurisdictions. Few locals possess the resources, capacity or strategic leverage to organize and bargain with the corporate builders who now dominate the industry.

Often, when a local union successfully organizes a regional contractor, the newly unionized employer is frustrated and mystified by the national union's structure. For example, a formerly non-union electrical contractor operating in Florida may sign a collective bargaining agreement with a local union based in Tampa. When this signatory employer successfully bids on a job in neighboring St Petersburg and sends his crew across the bridge from Tampa to the St Petersburg project site-which he routinely did prior to signing a contract with the Tampa local-he discovers that he has violated union rules that require that a certain number of his employees must now come from the St Petersburg local, that he pay a different wage rate in the St Petersburg local jurisdiction, and that he contribute to the health and welfare fund of the local where the project is undertaken. The line separating the Tampa and St Petersburg local union jurisdictions does not conform in any meaningful way to the actual structure and dynamics of the Florida construction market. In fact, while that 'imaginary' line retains great importance to the local unions, it presents itself as a real barrier to regional contractors who might otherwise be persuaded to sign collective bargaining agreements.

Some national building trades unions have addressed this structural problem with procedural adjustments. For example, locals are strongly encouraged to accept 'portability' agreements that allow contractors to move their core employees across local jurisdictions. Others have responded by merging local unions into larger, better-resourced locals whose expanded geographic jurisdictions conform more closely to actual construction markets. For example, the Laborers have consolidated 32 New Jersey locals into 16 unions; the Sheet Metal Workers have consolidated 20 California locals into five unions. International Union of Operating Engineers 
Local 3 has nearly 42,000 members throughout its jurisdiction of northern California, northern Nevada, Utah, and Hawaii, making it the largest construction trades local in the United States.

Several unions, including the Iron Workers, Painters, and Carpenters, have attacked this structural problem by creating regional councils that correspond to regional construction markets. In the Carpenters, President Doug McCarron has allowed local unions to maintain their essential identity, but the real power for organizing and bargaining has been transferred from local union officers to a powerful executive secretary-treasurer at the regional council. In some areas, this restructuring - with the increased resources and capacity it generated-has yielded impressive results. For example, the New England Regional Council of Carpenters - established in 1996has built a staff of over forty organizers drawn from the rank and file; increased its membership from 20,301 to 25,269 in 2004 , or about 24 percent; signed over 1,200 contractors; leveraged its power in strong union markets like Boston to compel employers to sign contracts covering all six New England states; and increased its market share from 79 percent to 92 percent in the Boston area, and from 38 percent to 54 percent throughout New England. ${ }^{55}$

All of these initiatives to restructure, centralize, and merge are intended to modernize decades-old structures that no longer correspond to the real world industry they are meant to service and organize. But these very efforts can create a new set of problems. Mergers may produce unintended negative consequences, i.e. mega-locals headquartered in large metropolitan centers may remove the union's presence in smaller communities and the ability to influence local politics. In addition, the move to centralize policy development and increase accountability may eliminate the balkanization of local autonomy and the ineffectiveness of competing and, occasionally, warring fiefdoms, but it can also undermine the perception or reality of democratic practices and diminish the members' sense of ownership of and loyalty to their organizations.

The second structural issue that demands attention is the contradiction between the need for a coordinated organizing strategy within national unions and the enduring tradition of local union autonomy. Even if the jurisdiction of a local union matches the rough geography of a definable construction market, there is no guarantee that the local will build the capacity and execute a strategy to organize the unrepresented workers and unionize the non-union contractors operating in that market. Historically, building trades locals have exercised a great deal of autonomy over their own affairs. This has been a strength of the building trades; members generally feel a deep sense of attachment to their local union. But since the late $1980 \mathrm{~s}$, when many national building trades leaders recognized the need to open the doors of formerly exclusive local unions in order to organize the rapidly growing non-union workforce, many local leaders have remained unwilling to implement the internal changes necessary to launch effective organizing programs. National unions have encouraged locals to 'change-to-organize' and used educational tools, like the COMET program, to persuade both local leaders and members of the need to organize. But when local leaders lacked the will or desire, they relied on the tradition of local autonomy to avoid the difficult challenge of organizing.

It is simply impossible to re-unionize an industry like construction - where nonunion employers and unorganized workers routinely cross local union jurisdictions - if one local union enthusiastically embraces its national union's commitment to organizing while a sister local in a neighboring area continues to ignore the nonunion threat and refuses to open its doors to unrepresented workers. National leaders have sometimes been reluctant to challenge the longstanding tradition of local autonomy. In 2004, the Iron Workers targeted J. D. Steel, one of the largest contractors in the reinforcing steel industry operating in several southwestern states.

\footnotetext{
55 These data exclude the 'Big Dig' mega-project.
} 
President Joe Hunt chartered a new organizing local-Regional Local 846-in part to avoid the internal politics and policies that sometimes impede effective organizing. Deploying a comprehensive strategy, the Iron Workers organized several hundred mostly immigrant rebar workers, supported them through a protracted strike, mobilized broad community and political support, and eventually signed J. D. Steel to a multi-state collective bargaining agreement.

In some rare cases, recalcitrant local unions have been put in trusteeship or merged into other locals. In the IBEW, President Ed Hill recently reclaimed the charter of Local 637, formerly based in Roanoke, Virginia, and divided its jurisdiction among locals in Washington, DC and West Virginia. This intervention was precipitated by the failure of Local 637 to enact a serious organizing program while the union's share of the local construction market shrank to about three percent. 'Did I enjoy doing that?' asked President Hill. 'Absolutely not. Nobody likes to play the heavy ... The time for anger was over when they failed to organize ... That's when people should have gotten angry. ${ }^{56}$ How can a leader drive a national organizing program when the union's internal structure is built on and deferential to the tradition of local autonomy? How can a union conduct a national program in a disciplined and effective way without establishing and enforcing standards of accountability for its constituent local affiliates?

However difficult it may be for national unions to resolve this autonomy dilemma, it is even more challenging for the Building and Construction Trades Department and its state and local councils. Conducting the kind of coordinated campaigns needed to reorganize the construction industry requires the active and authentic participation of multiple, independent craft unions. Building trades councils-like the AFL-CIO department to which they are affiliated-are voluntary associations that have not generally been able to achieve the level of unity and discipline required for such multi-union campaigns.

This is the third structural conundrum that confronts building trades leaders struggling to revitalize their movement. Leaders of the 15 building trades affiliates generally concede that they cannot individually organize their own craft in the nonunion industry in isolation from the other trades. This recognition fueled the Building Trades Organizing Project (BTOP) and other less ambitious multi-trade campaigns. The Las Vegas project revealed how difficult it was to devise a common organizing strategy that each affiliate would pursue. The voluntary nature of affiliate participation meant that each union ultimately chose its own path. While some affiliates genuinely embraced BTOP's mission, others abandoned the project when it was convenient to do so. The voluntary nature of the building trades structure - at the local and national levelsprecludes the possibility of establishing and enforcing the clear standards of accountability and discipline that multi-union organizing campaigns like BTOP require.

Some campaigns inevitably require multi-union participation. A sizable concrete foundation subcontractor, for example, may employ carpenters, cement finishers, ironworkers, laborers, and truck drivers. Under the present union structures, an organizing drive against this kind of target would involve the cooperation of up to five separate unions. If all of the relevant craft locals in that particular geographical jurisdiction do not have similar open door policies, organizing resources and staff, internal systems of accountability, and a willingness to set aside parochial concerns in favor of a joint effort, the campaign will not be able to speak forcefully to the employer or advocate for the entire workforce and, thus, is doomed to an early failure. The alternative-a 'wall-to-wall' campaign launched by the most highly motivated and bestpositioned affiliate-will immediately challenge traditional jurisdictional demarcations and spark a war of angry recriminations between the affected unions.

\footnotetext{
${ }^{56}$ Edwin D. Hill, International president, speech to IBEW Construction Business Managers, St Charles, IL, 30 August 2004.
} 
The fourth structural problem that the building trades face is the mismatch between the craft-based unionized sector and the actual organization of work in the dominant non-union sector. Many building trades leaders admit - though rarely for public attribution-that there are simply too many affiliates in the unionized sector of the industry. Historically, these affiliates grew out of well-defined crafts and have jealously protected their jurisdictions for over a hundred years. But this rigid craft orientation, and the 15 affiliates it supports, poses a two-fold problem. First, work in the unionized sector of the industry has evolved in ways that sometimes blur these craft lines. Without a strategy for union growth, the risk of jurisdictional disputes within the unionized sector increases. Second, when building trades unions attempt to organize the nonunion market, they discover that their strict craft jurisdictions are neither reflected nor respected in the organization of open shop work. Specialty contractors employing individual crafts exist in the non-union sector of the industry, but there are not 15 separate and distinct crafts. The structure of the building trades - with 15 different affiliates-does not match the structure of the non-union industry that must be organized.

Even in those cases where a relatively distinct trade still exists in the non-union sector of the industry, the affiliate claiming jurisdiction for that work may be too small and underresourced to effectively organize it. When that is true, merging with other affiliates may have a compelling logic. But whether and how the 15 building trades might consolidate into fewer organizations is one of the most vexing questions facing construction union leaders After 26 years as BCTD president, Robert A. Georgine suggested in his farewell address that it 'makes sense' for some of the smaller unions to join ranks with larger building trades affiliates. But his successor, Edward C. Sullivan, expressed no particular interest in tackling what he describes as a 'touchy subject. ${ }^{57}$ It is hard to imagine many of the smaller national unions voluntarily merging into larger, better-resourced organizations. There may be too much trade identity and craft pride standing in the way. On the other hand, even in the best of cases there are inherent limitations to what smaller affiliates can achieve. For example, the Roofers Union-which has shown talent and tenacity in conducting comprehensive campaigns - has fewer than 30,000 active members and may simply lack the resources and capacity to reorganize the non-union roofing industry on its own.

While it may be necessary for the building trades to address these and other architectural issues, structural remedies alone are not enough to rebuild an unstable House of Labor. Many leaders have suggested that the labor movement, in general, and the building trades, in particular, pay insufficient attention to identifying and developing new leaders with the analytical skills, strategic vision, and political courage to revitalize organized labor. Ironically, building trades unions invest considerable time and resources into training apprentices who engage in classroom study and supervised fieldwork to acquire the requisite skills and knowledge to become journeylevel craftsmen and -women. This process often takes four or five years. But even those building trades unions that offer aspiring leaders formal and systematic training have not yet raised leadership development to the level of journeymen and apprentice training.

Building trades unions can be just as relevant to solving today's problems in construction as they were a century ago. Declining union density has resulted in an industry defined by undesirable working conditions and endemic labor shortages. The rise of the open shop sector has produced a race to the bottom. Some open-minded contractors and construction users agree and acknowledge that unions have historically helped stabilize an inherently unstable industry and are cautiously encouraging new alliances. Joint labor-management efforts can be helpful in

\footnotetext{
${ }^{57}$ Engineering News Record, 10 April 2000, 15.
} 
arenas where mutual interests overlap but, in the final analysis, unions will have to shape their own destiny and overcome the structural mismatches that hinder effective growth strategies. The experimentation of the last decade has resulted in the development of a number of tactics and options that point to promising new directions. The tasks of restructuring for growth, modernizing outdated practices, mobilizing the existing membership, and organizing the armies of the unorganized are the preconditions of a building trades revitalization. There is a plausible scenario in which unions are now poised to learn the lessons and hard truths from the past forty years winnow through the approaches that work, and discard the policies that have failed. Only with a rebirth of construction unionism can the men and women who build our buildings, roads, and bridges return to the solid standards and higher blue-collar status they once enjoyed.

\section{References}

Bosch, G., and P. Philips. Building Chaos: An International Comparison of Deregulation in the Construction Industry. London and New York: Routledge, 2003.

Breslin, M. Organize or Die. Castro Valley, CA: McAlly International Press, 2003.

Eisenberg, E. 'Construction Wages and Labor Supply.' Housing Economics, March 2000, 7.

Fletcher, M. 'Bush Immigration Plan Meets GOP Opposition.' Washington Post, 2 January 2005, A6.

Grabelsky, J. 'Lighting the Spark: COMET Program Mobilizes the Ranks for Construction Organizing.' Labor Studies Journal (Summer 1995): 4-21.

Justich, R., and B. Ng. ' The Underground Labor Force Is Rising to the Surface.' Bear Stearns, 3 January $2005,2$.

Lerner, S. 'An Immodest Proposal: A New Architecture for the House of Labor.' New Labor Forum 12, no. 2 (2003): 9-30.

McTague, J. 'Going Underground.' Barron's, 3 January 2005, 18.

Millman, J. 'Blueprint for Outsourcing.' Wall Street Journal, 3 March 2004, B1, B4.

O'Hanlon, T. ' The Unchecked Power of the Building Trades. 'Fortune, December 1968, 102.

Perez, E. 'Construction Industry Split over Training Proposals.' Wall Street Journal, 9 February $2000, \mathrm{~F} 1$.

Wells, J. ' The Construction Industry in the Twenty-First Century: Its Image, Employment Prospects and Skill Requirement.' International Labour Organization, Geneva, 2001. 